\title{
Biological functions of hCG and hCG-related molecules
}

\author{
Laurence A Cole
}

\begin{abstract}
Background: hCG is a term referring to 4 independent molecules, each produced by separate cells and each having completely separate functions. These are hCG produced by villous syncytiotrophoblast cells, hyperglycosylated hCG produced by cytotrophoblast cells, free beta-subunit made by multiple primary nontrophoblastic malignancies, and pituitary hCG made by the gonadotrope cells of the anterior pituitary.

Results and discussion: hCG has numerous functions. hCG promotes progesterone production by corpus luteal cells; promotes angiogenesis in uterine vasculature; promoted the fusion of cytotrophoblast cell and differentiation to make syncytiotrophoblast cells; causes the blockage of any immune or macrophage action by mother on foreign invading placental cells; causes uterine growth parallel to fetal growth; suppresses any myometrial contractions during the course of pregnancy; causes growth and differentiation of the umbilical cord; signals the endometrium about forthcoming implantation; acts on receptor in mother's brain causing hyperemesis gravidarum, and seemingly promotes growth of fetal organs during pregnancy.

Hyperglycosylated hCG functions to promote growth of cytotrophoblast cells and invasion by these cells, as occurs in implantation of pregnancy, and growth and invasion by choriocarcinoma cells. hCG free beta-subunit is produced by numerous non-trophoblastic malignancies of different primaries. The detection of free beta-subunit in these malignancies is generally considered a sign of poor prognosis. The free beta-subunit blocks apoptosis in cancer cells and promotes the growth and malignancy of the cancer. Pituitary hCG is a sulfated variant of hCG produced at low levels during the menstrual cycle. Pituitary hCG seems to mimic luteinizing hormone actions during the menstrual cycle.
\end{abstract}

\section{Introduction}

It is difficult to say who specifically was the discoverer of the hormone we call hCG. In 1912, Aschner stimulated the genital tract of guinea pigs with injections of a water-soluble extracts of human placenta [1]. In 1913, Fellner induced ovulation in immature rabbits with a saline extracts of human placenta [2]. In 1919, Hirose stimulated ovulation and normal luteal function in immature rabbits by repeated injection of human placental tissue [3]. All of these works show that there was a clear hormonal link between the placenta and the uterus [1-3]. In 1927, Ascheim and Zondek demonstrated that pregnant women produce a gonad-stimulating substance [4]. They showed that injecting this substance into intact immature female mice let to

Correspondence: larry@hcglab.com

USA hCG Reference Service, University of New Mexico, Albuquerque NM 87131, USA follicular maturation, ovulation, and hemorrhaging into the ovarian stroma. Around this time, the name human chorionic gonadotropin (hCG) was conceived: Chorion comes from latin chordata meaning afterbirth; gonadotropin because the hormone is a gonad tropic molecule, acting on the ovaries, promoting steroid production.

As we know today, hCG is a hormone comprising an $\alpha$-subunit and a $\beta$-subunit which are held together by non-covalent hydrophobic and ionic interactions. The molecular weight of hCG is approximately 36,000 . It is an unusual molecule in that $25-41 \%$ of the molecular weight is derived from the sugar side-chains $(25-30 \%$ in regular hCG and $35-41 \%$ in hyperglycosylated hCG). Today, the function of hCG is still marked as being progesterone promotion in most medical student text books, but we now know now that hCG has numerous other important placental, uterine and fetal functions in pregnancy. From the time of implantation, hCG 
produced by trophoblast cells take over corpus luteal progesterone production rom luteinizing hormone (LH), acting on a joint hCG/LH receptor. This continues for approximately 3 to 4 weeks. After that time, there are sufficient syncytiotrophoblast cells in the placenta to take over progesterone production from corpus luteal cells.

Research now shows that there are at least 4 independent variants of hCG, each produced by different cells with separate biological functions. All the molecules share a common hCG $\beta$-subunit amino acid sequence. There is hCG, produced by differentiated syncytiotrophoblast cells or more specifically villous syncytiotrophoblast cells as pregnancy progresses [5-7]. This is the molecules that promotes progesterone production by ovarian corpus luteal cells and has multiple other biological functions as described below. Hyperglycosylated hCG is a sugar variant of hCG made by root cytotrophoblast cells or extravillous cytotrophoblast cells as pregnancy progresses [6,7]. Hyperglycosylated hCG is not a hormone but is an autocrine, acting on cytotrophoblast cells to promote cell growth and invasion as in implantation of pregnancy and invasion by choriocarcinoma cells $[8,9]$. Free $\beta$-subunit is the alternatively glycosylated monomeric variant of hCG made by all non-trophoblastic advanced malignancies [10]. Free $\beta$ subunit promotes growth and malignancy of advanced cancers $[11,12]$. A fourth variant of hCG is pituitary hCG, produced during the female menstrual cycle. This molecules has sulfated rather than sialylated oligosaccharides. Pituitary hCG functions in an LH-like manner to promote follicular maturation, stigma formation and meiosis in the primary follicle, ovulation, luteinization of the follicle, and progesterone production during the menstrual cycle $[13,14]$. The biological activities of all 4 variants of hCG and the actions of the hCG/LH receptor are carefully investigated in this review.

The serum and urine concentration of hCG and hyperglycosylated hCG during pregnancy are investigated in this comprehensive review. The extreme variations of hCG and hyperglycosylated hCG concentration are examined and how the extreme concentrations are managed by the hCG/LH receptor are investigated. hCG binds a common receptor with LH, the LH/hCG receptor. The specificity of the receptor and mechanism of receptor action are also considered in this review.

\section{Biological function of hCG}

The hormone hCG comprises an $\alpha$-subunit and a $\beta$ subunit. The $\alpha$-subunit is common to hCG, to the autocrine/paracrine hyperglycosylated hCG, to the hormone pituitary hCG, and to the hormones LH, follicle stimulating hormone $(\mathrm{FSH})$, and thyroid stimulating hormone (TSH), and to the common free $\alpha$-subunit formed in excess. The $\beta$-subunit of hCG, while structurally somewhat similar to the $\beta$-subunit of LH, differentiates hCG, hyperglycosylated hCG, and pituitary hCG from other molecules. Both hCG and LH bind and function through a common hCG/LH receptor. The biggest difference between LH and hCG is that LH, pI 8.0, has a circulating half-life of just 25-30 minutes [15], while hCG, pI 3.5, has a circulating half-life of approximately 37 hours [16], or 80 -fold longer than that of LH. In many respects hCG is a super LH produced in pregnancy, with $80 \mathrm{X}$ the biological activity of $\mathrm{LH}$, yet acting on the joint receptor. While LH, FSH and TSH are made by the anterior lobe of the pituitary, hCG is produced by fused and differentiated placental syncytiotrophoblast cells [6].

The original biological activity of hCG was first revealed in the nineteen twenties and confirmed and elaborated in the years that followed [1-4,17-23]. With pregnancy, hCG takes over from LH in promoting progesterone production by ovarian corpus luteal cells, preventing menstrual bleeding (Table 1). As we know today, hCG only promotes progesterone production for 3-4 weeks following pregnancy implantation. This function is active for approximately $10 \%$ of the length of pregnancy. As shown in Tables 2 and 3 hCG reaches a peak at 10 weeks of gestation, or almost one month after progesterone promotion is complete, then continues to be produced through the length of pregnancy. Clearly, progesterone production is not the principal purpose of hCG. As illustrated in Table 1, hCG has been shown in recent years to have numerous functions in the placenta, uterus and possible in the fetus during pregnancy.

The research groups of Rao et al., Zygmunt et al., and Noel et al., have each shown that hCG also functions to promote angiogenesis and vasculogenesis in the uterine vasculature during pregnancy. This insures maximal blood supply to the invading placenta and optimal nutrition to the fetus [24-30] (Table 1). The hCG/LH receptor gene is expressed by uterine spiral arteries, and hCG acts on them to promote angiogenesis. This is probably a major function of hCG during the course of pregnancy insuring adequate blood supply or nutrition to the placenta. hCG also has an important function at the placenta trophoblast tissue level promoting the fusion of cytotrophoblast cells and their differentiation to syncytiotrophoblast cells $[31,32]$ (Table 1). Testicular gem cell cancers take on trophoblast cytology. hCG may function similarly to promote differentiation of testicular cancer cytotrophoblast cell.

Four independent research groups showed that hCG promotes an anti-macrophage inhibitory factor or a macrophage migration inhibitory factor, a cytokine that modulates the immune response during pregnancy, 
Table 1 The biological functions of the isoforms of hCG.

\begin{tabular}{|c|c|}
\hline Function & References \\
\hline \multicolumn{2}{|l|}{ A. hCG } \\
\hline 1. Promotion of corpus luteal progesterone production & {$[1-4,17-23]$} \\
\hline 2. Angiogenesis of uterine vasculature & [24-30] \\
\hline 3. Cytotrophoblast differentiation & [31] \\
\hline 4. Immuno-suppression and blockage of phagocytosis of invading trophoblast cells & [32-38] \\
\hline 5. Growth of uterus in line with fetal growth & {$[39,40]$} \\
\hline 6. Quiescence of uterine muscle contraction & {$[39,41-43]$} \\
\hline 7. Promotion of growth and differentiation of fetal organs & [44-49] \\
\hline 8. Umbilical cord growth and development & {$[51-53]$} \\
\hline 9. Blastocysts signals endometrium prior to implantation & [54-56] \\
\hline 10. hCG in sperm and receptors found in fallopian tubes suggesting pre-pregnancy communication & {$[57-60]$} \\
\hline 11. hCG receptors in adult brain hippocampus, hypothalamus and brain stem, may cause pregnancy nausea and vomiting & {$[61,62]$} \\
\hline 12. hCG and implantation of pregnancy, hCG stimulates metalloproteinases of cytotrophoblast cell. & [64-67] \\
\hline \multicolumn{2}{|l|}{ B. Hyperglycosylated hCG } \\
\hline $\begin{array}{l}\text { 1. Stimulates implantation by invasion of cytotrophoblast cells as occurs at implantation of pregnancy, blocks apoptosis and growth } \\
\text { and malignancy of choriocarcinoma cells. }\end{array}$ & {$[8,9,71,74]$} \\
\hline 2. Stimulates growth of placenta and malignant placenta by promoting growth of cytotrophoblast cells & {$[9,74]$} \\
\hline \multicolumn{2}{|l|}{ C. Free $\beta$-subunit } \\
\hline 1. Blockage of apoptosis in no-trophoblastic malignancies, promotion of growth and malignancy & {$[83,85,91-95]$} \\
\hline \multicolumn{2}{|l|}{ D. Pituitary hCG } \\
\hline $\begin{array}{l}\text { 1. Seemingly mimics LH functions, promoting follicular growth, meiosis, stigma formation, ovulation, luteogenesis and promoting } \\
\text { progesterone production. }\end{array}$ & {$[121,122]$} \\
\hline
\end{tabular}

which reduces macrophage phagocytosis activity at the placenta-uterine interface, preventing destruction of foreign fetoplacental tissue [33-35] (Table 1). Three other groups have shown that hCG may directly suppress any immune action against the invading foreign tissue [36-38]. All told, hCG appears to be one of the numerous factors acting to prevent rejection of the fetoplacental tissue. Most observations suggest that hCG has an inhibitory or suppressive function on macrophage activity. One group, Wan et al. [35] demonstrated that hCG can directly enhance innate immunity by stimulating macrophage function.

Multiple groups have found hCG/LH receptor in the myometrium of the uterus. It has been indicated by two groups that uterine growth in line with fetal growth may be stimulated by hCG, so that the uterus expands with fetal size during pregnancy $[39,40]$ (Table 1). Four groups have shown that hCG relaxes myometrial

Table 2 Concentration of total hCG and hyperglycosylated hCG (hCG-H) in 496 serum samples from 310 women with term pregnancies measured using the Siemens Immulite 1000 total hCG assay.

\begin{tabular}{|c|c|c|c|c|c|c|}
\hline $\begin{array}{c}\text { Gestation age (weeks since start of } \\
\text { menstrual period) }\end{array}$ & $\mathbf{N}$ & $\begin{array}{l}\text { Median Total } \\
\text { hCG ng/ml }\end{array}$ & $\begin{array}{c}\text { Range Total } \\
\text { hCG } \mathrm{ng} / \mathrm{ml} \text { (variation) }\end{array}$ & $\begin{array}{c}\text { Median HCG-H } \\
\mathrm{ng} / \mathrm{ml}\end{array}$ & $\begin{array}{l}\text { Range hCG-H ng/ml } \\
\text { (variation) }\end{array}$ & $\begin{array}{l}\text { hCG- } \\
\text { H \% }\end{array}$ \\
\hline 3-weeks-3-weeks 6-days & $n=42$ & $\begin{array}{l}0.26(16 \text { of } 42 \\
<0.1 \mathrm{ng} / \mathrm{ml})\end{array}$ & $0.04-5.5$ & $\begin{array}{l}0.20(16 \text { of } 42 \\
<0.1 \mathrm{ng} / \mathrm{ml})\end{array}$ & $0.01-6.45$ & $87 \%$ \\
\hline 4 weeks-4 weeks 6 -days & $n=42$ & 3.4 & $0.21-173(824 X)$ & 2.5 & $0.18-160(888 X)$ & $51 \%$ \\
\hline 5 weeks-5-weeks 6-days & $n=67$ & 65 & $1.86-1308(704 X)$ & 8.6 & $0.96-698(731 X)$ & $43 \%$ \\
\hline 6-weeks-6-weeks 6-days & $n=29$ & 252 & $3.80-855(225 X)$ & 86 & $0.76-629(827 X)$ & $36 \%$ \\
\hline 7 weeks-7 weeks 6-days & $n=30$ & 3,278 & $203-7,766(38 X)$ & 359 & $27-931(34 X)$ & $16 \%$ \\
\hline 8 weeks- 8 weeks 6 -days & $n=33$ & 4,331 & $1,064-10,057(9.4 X)$ & 386 & $67-1050(15.6 X)$ & $7.0 \%$ \\
\hline 9 weeks-9 weeks 6-days & $n=24$ & 5,832 & $1,031-11,586(11.2 X)$ & 430 & $102-1158(11.3 X)$ & $5.1 \%$ \\
\hline 10 weeks-10 weeks 6-days & $n=20$ & 10,352 & $1,952-19,958(10.2 X)$ & 521 & $188-1855(9.9 X)$ & $4.3 \%$ \\
\hline 11 weeks-13-weeks 6-days & $\mathrm{n}=41$ & 5,953 & $1,440-15,318(10.6 X)$ & 137 & $24-330(13.7 X)$ & $2.3 \%$ \\
\hline 14 weeks-17 weeks 6-days & $\mathrm{n}=57$ & 2,934 & $311-4,757(15.2 X)$ & 26 & $6.7-129(19.3 X)$ & $1.3 \%$ \\
\hline 18 weeks-26-weeks 6-days & $\mathrm{n}=62$ & 1,931 & $210-6,223(30.3 X)$ & 15.8 & $5.3-95(17.9 X)$ & $0.65 \%$ \\
\hline 27 weeks-40 weeks 6-days & $n=49$ & 1,911 & $184-8,530(46.4 X)$ & 2.95 & $0.3-12.2(40.6 X)$ & $0.14 \%$ \\
\hline
\end{tabular}

Data from 50 pregnancies that failed due to miscarriage were excluded from this table. Pregnancies which failed to implant in early pregnancy (total hCG <0.1 $\mathrm{ng} / \mathrm{ml}$ ) are indicated in parenthesis. 
Table 3 Concentration of total hCG and in 4246 urine samples from 574 women having term pregnancies measured using the Siemens Immulite 1000 total hCG assay.

\begin{tabular}{|c|c|c|c|c|}
\hline Gestation age (weeks since start of menstrual period) & $\mathbf{N}$ & $\begin{array}{l}\text { Median Total } \\
\text { hCG ng/ml }\end{array}$ & $\begin{array}{c}\text { Range Total } \\
\text { hCG ng/ml (variation) }\end{array}$ & Variance \\
\hline 3-weeks-3-weeks 6-days & $n=574$ & $0.24(255$ of $574<0.1 \mathrm{ng} / \mathrm{ml})$ & $0-415$ & \\
\hline 4 weeks-4 weeks 6-days & $n=574$ & 21.7 (20 of $574<0.1 \mathrm{ng} / \mathrm{ml}$ ) & $0-213$ & \\
\hline 5 weeks-5-weeks 6-days & $n=574$ & 301.2 & $2.3-4,195$ & $1839 x$ \\
\hline 6-weeks-6-weeks 6-days & $n=574$ & 1,472 & $14.1-24,580$ & $1743 x$ \\
\hline 7 weeks-7 weeks 6-days & $\mathrm{n}=574$ & 4,795 & $93.1-28,370$ & $305 x$ \\
\hline 8 weeks-8 weeks 6 -days & $n=574$ & 6,813 & $124.5-42,120$ & $338 X$ \\
\hline 9 weeks-9 weeks 6 -days & $n=65$ & 8,869 & $134.5-54,530$ & $405 x$ \\
\hline 10 weeks-10 weeks 6-days & $n=45$ & 9,864 & $123.4-60,130$ & $487 X$ \\
\hline 11 weeks-13-weeks 6-days & $n=74$ & 1,984 & $179.3-49,540$ & $276 X$ \\
\hline 14 weeks-17 weeks 6-days & $n=494$ & 768.8 & $58.5-8,411$ & $143 x$ \\
\hline 18 weeks-26-weeks 6-days & $n=74$ & 506.3 & $84.0-2,643$ & $31.5 x$ \\
\hline 27 weeks-40 weeks 6-days & $\mathrm{n}=50$ & 522.4 & $66.1-1,873$ & $28.3 X$ \\
\hline
\end{tabular}

Data from a further 97 pregnancies that failed (miscarriage) were excluded from this table. Pregnancies which failed to implant in early pregnancy (total hCG $<0.1 \mathrm{ng} / \mathrm{ml}$ ) are indicated in parenthesis.

contractions during the course of pregnancy. hCG acts on a BK-Ca calcium activated channel to relax to myometrium during the course of pregnancy [39,41-43]. hCG levels drop during the final weeks of pregnancy. It has been suggested that this drop may be the cause of increased contractions in the weeks prior to delivery.

Exciting new research is finding hCG/LH receptors in fetal organs. Goldsmith et al. [44], have found hCG/LH receptors in the fetal kidney and liver. Rao et al. [45-49], have located hCG/LH receptors in the lung, liver, kidneys, spleen, and small and large intestines. Interestingly, this hCG/LH receptor is present in the fetal organs but completely absent in the adult organs. It is suggested that hCG may promote organ growth and differentiation in the fetus. The human fetus might produce its own hCG from the kidneys and liver [44,50]. The concentrations of hCG in the fetal circulation, however, are much lower than maternal concentrations, suggesting that placental hCG secretion is directed towards the maternal circulation and it is prevented from entering into fetal circulation [50]. While hCG/LH receptor has been shown in fetal organs, no function has been directly demonstrated, just indicated by the presence of receptor. As such, all the findings regarding the fetus have to be considered as just suggestions at this time. Unfortunately, all animals except advanced primates do not make a form of hCG, making the role of hCG in the fetus difficult to confirm.

hCG has also been shown to function in umbilical cord growth and development [51,52]. It is interesting that hCG and hyperglycosylated hCG work together to promote the growth (growth of root cytotrophoblast cells, hyperglycosylated hCG) and differentiation (promoted by hCG) of the placenta, and promotion of the uterine blood supply to meet the invading placenta (promoted by hCG). The next step is the development of the umbilical cord and circulation. This is also seemingly promoted by hCG, suggesting hCG and hyperglycosylated hCG involvement in multiple steps of placentation and fetal development [44-49,51-53].

Multiple publications suggest a signaling occurs between the unimplanted blastocyst and the decidua tissue [54-57]. Four independent reports show that the blastocyst preimplantation secretes hCG into the uterine space which is taken up by $\mathrm{hCG} / \mathrm{LH}$ receptors on the endometrial surface (Table 1). In response, the endometrium is prepared for an impending implantation [54-57]. These non-vascular communications by hCG are a critical part of successful pregnancy. Recent studies show the importance of a receptive endometrium and of hCG preimplantation signaling in a successful pregnancy [58-60]. hCG signaling directly causes immunotolerance and angiogenesis at the maternal fetal interface. hCG increases the number of uterine natural killer cells that play a key role in the establishment of pregnancy [58-60].

Other new data shows other pre-pregnancy implantation function of hCG. Publications from Rao et al. [61-63] and by Gawronska et al. [63], shows the presence of an hCG/ $\mathrm{LH}$ receptor (shown by presence of mRNA and demonstration of receptor action) in human sperm and in the fallopian tubes (Table 1). The function of the hCG/LH receptor in sperm is unclear. It possibly has some relationship to fertility. The hCG/LH receptor in the fallopian tubes may be that which is acted on by $\mathrm{LH}$, which relaxes the fallopian tube for fertilization to take place.

It has long been speculated that hCG may have a role in implantation of pregnancy [64-67]. Publications suggest an autocrine or paracrine function of hCG in implantation of pregnancy. hCG of implantation is seemingly produced by cytotropblast cells. However, hCG 
is an endocrine. We now know from recent research that a variant of hCG, hyperglycosylated hCG, rather than hCG itself, is produced by cytotrophoblast cells $[6,7]$. Hyperglycosylated hCG is an autocrine or paracrine and has been shown to directly promote implantation of pregnancy $[6,8,9]$. This is seeming what was considered the hCG implantation function. Hyperglycosylated hCG and its role in implantation of pregnancy are reviewed in Section 3. A recent study by Fluhr and collages [65], suggest a direct role of hCG in cytotrophoblast cell metalloproteinase production, this could be true and needs careful investigation.

Finally, the hCG/LH receptor has been demonstrated in adult women's brains. CNS receptors are present in several areas of the brain such as the hippocampus, hypothalamus and brain stem $[68,69]$ (Table 1). The finding of an hCG receptor in these parts of the brain may explain the hyperemesis gravidarum or nausea and vomiting that occurs during normal pregnancy.

All told, hCG has a very wide range of actions through the hCG/LH receptor. hCG and hyperglycosylated hCG seemingly act to together to promote the growth and differentiation of trophoblast cells or formation of the placenta villous structures. They seemingly start their action early with blastocyst signaling of the endometrium of forthcoming implantation. Hyperglycosylated hCG then promotes implantation and growth of cytotrophoblast cells. hCG promotes the differentiation of cytotrophoblast cells to syncytiotrophoblast cells and so the villous structures which are mixture of the two cell types are formed. hCG also promotes the uterine vasculature to maximally provide blood to the hemochorial placentation structure. hCG also acts on the fetus to promote growth and differentiation of fetal organs. During this time hCG acts on the maternal brain to promote hyperemesis gravidarum. Taking everything together, hCG and hyperglycosylated hCG are the hormone and autocrine that seemingly control pregnancy.

\section{Biological function of hyperglycosylated hCG}

Hyperglycosylated hCG is a glycosylation variant of hCG produced by root cytotrophoblast cells and extravillous cytotrophoblast cells [6,7]. It shares the amino acid sequences of the $\alpha$ - and $\beta$-subunit of hCG with 8 oligosaccharides side chains. While hCG has monoantennary (8 sugar residues) and biantennary (11 sugar residues) $\mathrm{N}$ linked oligosaccharides, and mostly trisaccharide O-linked oligosaccharides (3 sugar residues), hyperglycosylated hCG has mostly larger fucosylated triantennary (15 sugars) $\mathrm{N}$-linked oligosaccharides and double-size hexasaccharide O-linked oligosaccharides (6 sugar residues). As a result the molecular weight of hCG is 36,000 , while the molecular weight of hyperglycosylated hCG is 40,000 to 41,000 , dependent on extent of hyperglycosylation. The additional sugars structures on hyperglycosylated hCG seeming prevent complete folding of the $\alpha \beta$ dimer. This exposes other receptor binding site on hyperglycosylated hCG. Common regions include a transforming growth factor beta (TGF $\beta$ )/ platelet-derived growth factor (PDGF)/Nerve growth factor (NGF) common cystine-knot related structure [70]. The function of hyperglycosylated hCG, blocking apoptosis [71], and a likely metalloproteinase promoting activity [72], suggests that hyperglycosylated hCG may be an antagonist of TGF $\beta$ receptor controlled functions in cytotrophoblast cells. While these pathways seems very likely from multiple studies of placental implantation, cytotrophoblast cell apoptosis, cytotrophoblast cells and metalloproteinases and placental invasion biology, that TGF $\beta$ receptor is involved in these actions [73-86]. This still needs to be proven by needed research. Hyperglycosylated hCG appear to acts by antagonizing a cytotrophoblast TGF $\beta$ receptor, seemingly blocking apoptosis and promoting invasion by metalloproteinases [71-86].

As shown, hyperglycosylated hCG is the principal variant of hCG produced in early pregnancy. Hyperglycosylated hCG comprises an average of $87 \%$ of the total hCG produced in serum during the third week, $51 \%$ during the fourth week and $43 \%$ during the fifth week of gestation (Table 2). Hyperglycosylated hCG levels then dwindles to $<1 \%$ of total hCG during the $2^{\text {nd }}$ and $3^{\text {rd }}$ trimesters of pregnancy. This is consistent with hyperglycosylated hCG having a function in promoting implantation in early pregnancy $[8,9,87]$.

Research clearly shows that hyperglycosylated hCG acts on choriocarcinoma cells (cancer of cytotrophoblast cells) promoting invasion $[9,10]$. Hyperglycosylated hCG is the principal variant of hCG made by choriocarcinoma cells $[9,10]$. The role of hyperglycosylated hCG in choriocarcinoma invasion has been demonstrated now by 3 independent groups, each showing that this molecules promotes invasion by choriocarcinoma cells in Matrigel chambers $[9,71,88]$. Other studies examine growth of choriocarcinoma cells transplanted into nude mice in vivo $[9,71,88]$. As demonstrated, blockage of hyperglycosylated hCG with a specific antibody to hyperglycosylated hCG, or by blocking $\alpha$ - and $\beta$-subunit DNA expression, totally blocks choriocarcinoma growth $[9,71,88]$. These finding all suggest the use of blockage agent such as an antibody to hyperglycosylated hCG in the treatment of choriocarcinoma. Other research indicates that hyperglycosylated hCG, the cytotrophoblast cell invasion promoter in choriocarcinoma, specifically promotes the invasion in implantation of pregnancy, and the deep implantation of the villous placental structures that is driven by extravillous cytotrophoblast cells $[6,8,87]$. These studies used the B152 assay for hyperglycosylated hCG. Laboratory experiments show that antibody to hyperglycosylated hCG, antibody B152, blocks 
growth of cytotrophoblast cell lines in vitro (JEG-3 and Jar cell line). Hyperglycosylated hCG promotes growth of cytotrophoblast cells, at implantation and in choriocarcinoma $[9,10,87]$.

As published $[89,90]$, two third of pregnancy failures, biochemical pregnancies and miscarriages of pregnancy, are due to failure of blastocysts to implant appropriately. The remaining one third of failures are due to hydatidiform mole or genetic abnormalities [89,90]. A total of 62 pregnancies were investigated. On the day of implantation of pregnancy, 42 of 42 term pregnancies produced only hyperglycosylated hCG in vivo (26 of 42 cases) or $>50 \%$ hyperglycosylated hCG of total hCG. As found, two third of failures (13 of 20) produced insufficient hyperglycosylated hCG or $<50 \%$ hyperglycosylated hCG of total hCG [8]. It is inferred that pregnancy failures are due to insufficient production of hyperglycosylated hCG leading to failure to implant appropriately. These studies used the B152 assay for hyperglycosylated hCG. Similar finding showing that hyperglycosylated hCG is a marker of pregnancy failure have been reported by Kovalevskaya et al [91], also using the B152 specific assay.

Similarly, hypertense disorders of pregnancy or preeclampsia in pregnancy are due to failure to appropriately connect the implanting villous hemochorial placentation with appropriate uterine blood supply $[92,93]$. Studies indicate that this may also be due to a deficiency of hyperglycosylated hCG [94].

In conclusion, hyperglycosylated hCG is the invasive signal of cytotrophoblast invasion of pregnancy implantation and choriocarcinoma invasion. Ineffective invasion due to insufficient hyperglycosylated hCG occurs in failed pregnancies, biochemical pregnancies and miscarriages, and seemingly in hypertense disorders of pregnancy.

\section{Biological function of free $\boldsymbol{\beta}$-subunit}

The free $\beta$-subunit produced is a hyperglycosylated variant of the $\beta$-subunit of hCG with triantennary $\mathrm{N}$-linked oligosaccharides and hexasaccharide type O-linked oligosaccharides $[95,96]$. Excess $\beta$-subunit or free $\beta$-subunit is produced in hydatidiform mole, choriocarcinoma, and almost exclusively by non-trophoblastic cancers of all primaries.

Studies by Acevedo et al. [96-98], show the presence of hCG free $\beta$-subunit in the membranes of all cancer cell lines in vitro, and in all histological samples (slides) of malignancies. This data is considered rather controversial. New data, however, seemingly confirms these findings in cervical cancer cells [99]. Other studies indicate a clear association between detection of free $\beta$-subunit in serum samples, or detection of its degradation product, $\beta$-subunit core fragment, in urine samples, with cases with poor grade and advanced stage cancer, or poor outcome malignancy [100-103].

In a review of different articles investigating free $\beta$-subunit as a prognostic marker in cancer, 12 of 13 studies demonstrated a clear correlation between expression of hCG free $\beta$-subunit and poor prognosis $[100,104]$. These studies together indicate that expression of free $\beta$-subunit leads to a negative outcome in human malignancies. Multiple reports now indicate that free $\beta$-subunit may have a specific role in malignant transformation of cells [97,99,105-109]. In these, and other studies, stimulation of malignant cell growth has been demonstrated by the action of free $\beta$-subunit [97,99,105-109].

Free $\beta$-subunit has a major role to play in nongestational neoplasm biochemistry, either as a promoter causing poor malignancy outcome or as an element involved in malignant transformation. Indeed, efforts are now being directed toward using different hCG $\beta$ subunit derivatives as vaccines in the treatment of non-gestational malignancies. Achievement has been reported, with hCG $\beta$-subunit immunity improving cancer outcome or cancer survival [110-114]. The association of free $\beta$ detection and poor prognosis, in combination with site specific hCG $\beta$-subunit vaccine technology suggests a plausible route to the development of adjuvant cancer therapies specifically targeting patients with free $\beta$-subunit producing non-gestational tumors.

Both hyperglycosylated hCG and free $\beta$ promote cancer cell growth and malignancy $[5,9,87,100,104,107,108]$, similarly, both hyperglycosylated hCG and free $\beta$ function by blocking or antagonizing apoptosis causing cell growth $[71,99,100,104,107,115]$. In the action of both hyperglycosylated hCG and free $\beta$ the use of the TGF $\beta$ receptor is indicated $[107,108,116-121]$. As reported, free $\beta$ is produced by bladder cancer cells and inhibits TGF $\beta$ activity in bladder cancer cells [122]. Free $\beta$-subunit antagonizes TGF $\beta$ functions in bladder cancer cells leading to growth and malignancy $[33,122]$. It is inferred that both hyperglycosylated hCG and hyperglycosylated hCG free $\beta$ function similarly, both promoting cell growth, invasion and malignancy by blocking apoptosis through antagonizing a TGF $\beta$ receptor. We hypothesize that they both bind the same receptor and function through similar pathways.

\section{Biological function of pituitary hCG}

Publications in the nineteen sixties, seventies and eighties suggested bacteria, crabs, and other bazaar sources to explain detection of hCG in non-pregnant individuals, including cancer cases [123-125]. We now have a better understanding of the various not pregnant sources of hCG. Possibilities today include non-trophoblastic 
cancer, as described in the preceding section, quiescent gestational trophoblastic disease [126], familial hCG syndrome [127], and as shown in this chapter pituitary hCG.

It is now been 30 years since hCG was first demonstrated to originate from the pituitary gland [128]. Since then, almost 40 publications have confirmed this observation and described how very low level hCG production accompanies luteinizing hormone (LH) production at the time of the mid-menstrual cycle pre-ovulatory surge, a normal part of normal pituitary physiology [128-134]. Most noticeably, pituitary derived hCG is normally elevated along with pituitary LH and FSH in women receiving an oophorectomy, during oligomenorrhea in perimenopause (age 40-50), and during amenorrhea in menopause (Age >50) [129-134]. In medical practice, a positive hCG test prior to menopause suggests pregnancy or gestational trophoblastic disease [132-134]. A positive hCG test in perimenopausal and menopause, can represent a predicament to physicians. When an hCG positive patient is referred to an oncologist, they may be considered as having gestational trophoblastic diseases or a non-gestational malignancy, and may be placed on chemotherapy or given hysterectomy with the hope that hCG will disappear. The hCG level will not change in patients treated this way, since it is natural hormone, pituitary hCG.

Pituitary hCG has an identical amino acid structure to pregnancy hCG. It is unique, however, in having a variable portion of sulfated oligosaccharides [133]. The sulfated groups are attached to $\mathrm{N}$-acetylgalactosamine residues, which replaces galactose and sialic acid residues in $\mathrm{N}$ - and O-linked oligosaccharides. As found pituitary hCG with sulfated oligosaccharides has a shorter circulating half life that pregnancy hCG [133].

As shown by Odell and Griffin [135,136], using an ultra-sensitive radioimmunoassay LH (sensitivity 0.005 $\mathrm{mIU} / \mathrm{ml}$ ), pituitary hCG is produced at very low levels (mean $0.01 \mathrm{mIU} / \mathrm{ml}$ ) in men, with a wide range of 0.03 to $1.7 \mathrm{mIU} / \mathrm{ml}$. Pituitary hCG was detected in women in pulses in the luteal and follicular phases of the menstrual cycle which paralleled LH levels $[135,136]$. Injections of Gonadotropin releasing hormone $(\mathrm{GnRH})$ were shown to directly promote circulating pituitary hCG levels in men and women, just as they similarly promotes LH levels $[135,136]$. It is inferred that pituitary hCG supplements pituitary LH in men and women $[13,136]$. The USA hCG Reference Service recently examined over 8300 urine samples from women with normal menstrual periods using the Siemens Immulite 1000 assay to total hCG $[13,136]$. As found, hCG (sensitivity $>1 \mathrm{mIU} / \mathrm{ml}$ ) was detected at the time of the midcycle LH peak in 232 of $277(84 \%)$ menstrual cycles. The mean hCG level was $1.54 \pm 0.90 \mathrm{mIU} / \mathrm{ml}$ and the range was $<1$ to $9.2 \mathrm{mIU} / \mathrm{ml}$. This recent study very much confirms the findings of Odell and Griffin showing that pituitary hCG mirrors pituitary LH levels $[135,136]$.

The mass of hCG stored in an individual human pituitary gland, 0.5-1.1 $\mu \mathrm{g} \mathrm{hCG}$ per gland, is approximately 25-50 fold less than the mass of LH [146]. Publications show that pituitary hCG has approximately half the biological activity in promoting progesterone production of placental hCG [133]. As such, it is 40 -fold more potent than pituitary LH [15]. As indicated by Odell and Griffin, circulating levels of hCG during the menstrual cycle are approximately $1 / 120$ th of circulating levels of $\mathrm{LH}$, $\mathrm{mIU} / \mathrm{ml}$ to $\mathrm{mIU} / \mathrm{ml}[135,136]$. Considering the 40 -fold greater potency of pituitary hCG, pituitary hCG may therefore have an average potency of approximately $1 /$ 3rd of the potency of LH. This makes pituitary hCG a significant pituitary hormone.

As yet, it is unknown whether there is a specific function for pituitary hCG during the menstrual cycle. Pituitary hCG could have functions separate from those of LH. But even if pituitary hCG has no specific function, there is a natural explanation for its production. There is a single LH $\beta$-subunit gene next to the 8 back-toback hCG $\beta$-subunit genes on human chromosome 19 (Figure 1) [137]. hCG and LH share a single common $\alpha$-subunit. It is possible, as indicated in Figure 1, that hCG $\beta$-subunit gene transcription is promoted consequentially by gonadotropin releasing hormone $(\mathrm{GnRH})$ alongside specific LH $\beta$-subunit stimulation in pituitary gonadotrope cells during normal menstrual cycle physiology in women and normal physiology in men.

LH has multiple functions during the LH peak and ovulation period. We know that both LH and hCG act on the hCG/LH receptor to promote progesterone production by corpus luteum cells [17-23]. We assume that LH and hCG act on the same receptor on granulosa and theca cells. As established, with the appearance of an hCG/LH receptor on granulosa cells of the Graafian follicle or primary follicle, LH first promotes follicular growth $[138,139]$, then stimulates diploid cell meiosis $[140,141]$. LH causes the follicle to form a stigma or protrusion [142], and then promotes collagenase production to degrade and penetrate the stigma $[142,143]$. The penetration of the stigma causes bursting of the follicle (ovulation) to occur. $\mathrm{LH}$ then acts to differentiate the burst or ovulated follicle into a corpus luteum $[144,145]$. It is not clear whether hCG just incidentally assists LH in each of these steps or has specific functions of its own in one or more of these steps.

\section{hCG and hyperglycosylated hCG variation}

hCG and associated molecules seeming have a wide array of biological activities. hCG and hyperglycosylated 


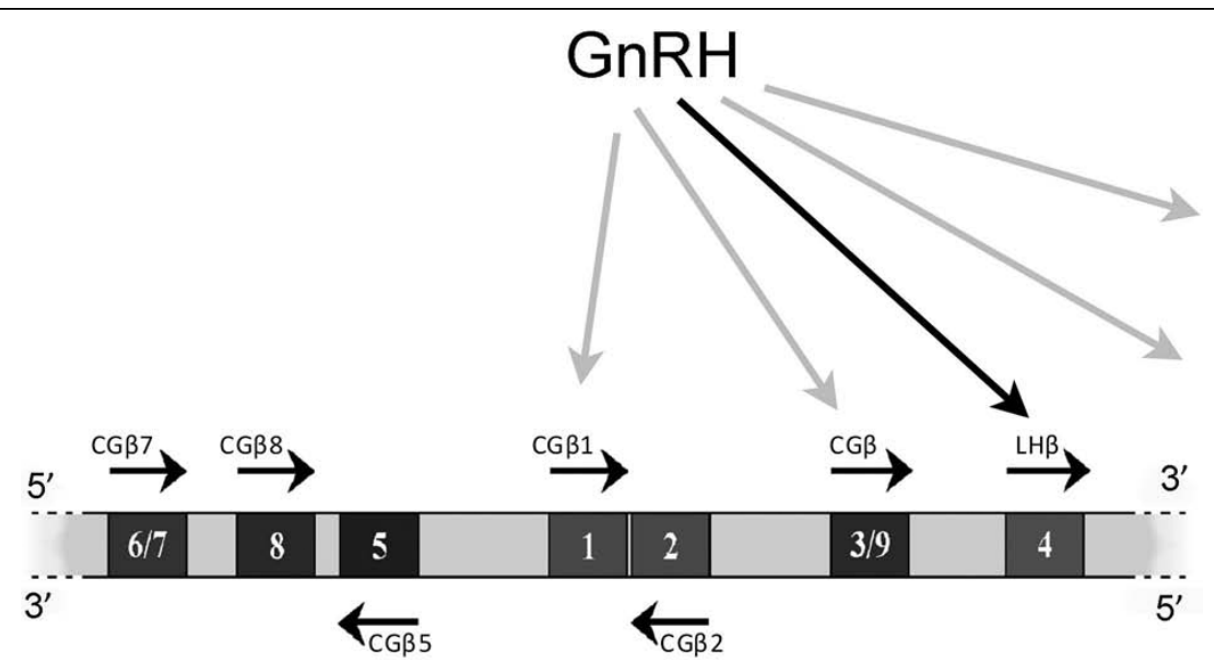

Figure $1 \mathrm{~A}$ diagrammatic representation of the arrangement of genes in the $\mathrm{LH} \beta / \mathrm{hCG} \beta$ gene cluster on chromosome 19q13.32. The gray arrows show the postulated chance stimulation of hCG $\beta$-subunit genes by the GnRH promoting LH $\beta$-subunit gene transcription.

hCG effective control placentation and fetal development during pregnancy. Considering these critical biological functions there is a major paradox that exists. That is that individual hCG levels in serum (Table 2) and urine (Table 3) of total hCG and hyperglycosylated hCG vary extremely widely. In serum, in the $4^{\text {th }}$ week of gestation (weeks following start of menstrual period), individual total hCG values vary by 824 -fold, between 0.21 and $173 \mathrm{ng} / \mathrm{ml}$ amongst different women with singleton term outcome pregnancies (all failing pregnancies removed from table) (Table 2). Hyperglycosylated hCG values vary even wider during this week of pregnancy, 888 -fold. In the $5^{\text {th }}$ week of gestation total hCG values vary by 704 fold, between 1.86 and $1308 \mathrm{ng} / \mathrm{ml}$ amongst different women with singleton term outcome pregnancies. Hyperglycosylated hCG values vary once again slightly wider, 734-fold. We ask how and why does this extremely wide variation exist with such important molecules between different pregnancies, and how with such extreme variation in signal, can all these pregnancies go to term and produce similar size babies? This is the subject of two articles. The first article addresses the cause of the wide variation [147], and the second article address the affect of the wide variation, or how the receptors cope with this situation [Cole LA, paper submitted to J Clin Endocrinol Metab].

As published [147], pregnancy data in normally anchored to the start of the last menstrual period. Implantation of term outcome pregnancy (biochemical pregnancies and miscarried pregnancies excluded) or the start of gestation occured, however, anywhere from day 16 to day 32 from this anchoring point in 82 woman with menstrual cycle of average length of $27.7 \pm$ 2.4 days $[147,148]$. In a 28 day cycle this can be considered as anywhere from 12 days prior to missing a menstrual period to 2 days after the time of missing a menstrual period. The day of implantation is 3 to 16 days after the LH peak. The day of implantation is the day of starting viable pregnancy. Dating this important date to the time of the start of the last menses (weeks of gestation) is a source of great variability $[147,148]$. If pregnancies were dated, however, to the day of implantation (difficult to measure and difficult as an anchor date), variation is dropped significantly [147]. Normally, at the $4^{\text {th }}$ week (28 days) since the last menstrual period urine hCG ranges from $<0.1 \mathrm{ng} / \mathrm{ml}$ to $213 \mathrm{ng} / \mathrm{ml}$ (Table 2 ). This suggests variation of $>2130$-fold. If the same pregnancies were dated to 7 days after the time of implantation, hCG ranges from just $3.1 \mathrm{ng} / \mathrm{ml}$ to 402 $\mathrm{ng} / \mathrm{ml}$ indicating a variation of just 131 -fold, a significant difference, $\mathrm{p}=0.00005$. Clearly dating pregnancies to time of implantation is preferable to dating to start of last menstrual period, but is difficult. Difficult in that it requires daily hCG measurements while attempting to achieve pregnancy to determine time of implantation. Clearly dating of pregnancies is a cause of variation.

Examining 594 pregnancies from implantation to term, only one other cause could be found for individual variations in hCG. That is hCG daily increase rate in the first 4 weeks following implantation. hCG daily increase rate was measured in 82 women (all results from women with biochemical or miscarried pregnancies removed) with term outcome pregnancies, from day of implantation for 28 days. The increase rate per day was averaged over the 28 days. The increase rate per day ranged from 1.52 -fold per day to 2.92 -fold per day among the 82 women [147]. If this is considered over 7 days then it is equivalent to $1.52^{7}$ and $2.92^{7}$ or to an 
increase of 18.7-fold vs. an increase of 1810-fold. Individual hCG daily amplification rate is also a major cause of variation.

It is a fact that pregnancy to pregnancy hCG levels vary greatly. How does the human body deal with these wide variations in hCG concentrations? How does each woman end up with a normal term delivery? This was carefully investigated [Cole LA, paper submitted to $J$ Clin Endocrinol Metab]. Most hCG and hyperglycosylated hCG-related parameters, like promotion of uterine vascular angiogenesis, promotion of implantation, differentiation of cytotrophoblast cells, growth and differentiation of fetal organs, are not readily measurable in normal term pregnancies. One hCG-related biological activity was, however, measurable, promotion of progesterone production by corpus luteal cells at 3-6 weeks of gestation. Serum progesterone was measured during the $4^{\text {th }}$ week of gestation, in those providing serum samples.

During the $4^{\text {th }}$ week of pregnancy serum hCG ranged widely from 0.21 to $173 \mathrm{ng} / \mathrm{ml}$ or variation of 824 -fold. Serum progesterone during this same period, in these same women, did no vary widely, 6.5 to $101 \mathrm{ng} / \mathrm{ml}$, or 16-fold (paper submitted to J Clin Endocrinol Metab). The median progesterone concentration was $22 \mathrm{ng} / \mathrm{ml}$. Interestingly, in the case with extremely low serum hCG concentration, $0.21 \mathrm{ng} / \mathrm{ml}$ or $23 \mathrm{mIU} / \mathrm{ml}$, the progesterone was slightly higher than the median, $36.1 \mathrm{ng} / \mathrm{ml}$. In the case with extremely high hCG concentration, 173 $\mathrm{ng} / \mathrm{ml}$ or $1903 \mathrm{mIU} / \mathrm{ml}$, the progesterone concentration was $11.4 \mathrm{ng} / \mathrm{ml}$, or slightly lower that the median. The hCG levels stretched 824-fold from 0.21 to $173 \mathrm{ng} / \mathrm{ml}$, but the resulting progesterone concentrations or biological activity stretched just 3.16-fold from 11.4 to $36.1 \mathrm{ng} /$ $\mathrm{ml}$, why we ask?

This is apparently due to the $\mathrm{hCG} / \mathrm{LH}$ receptor spare receptor concept [149-151]. Under the spare receptor concept, when only a tiny proportion of receptors is activated in a cell it may yield a similar cellular response to all receptors on the cell being activated [149-151]. This is the best explanation of these findings. Similarly, in cases with extremely high serum hCG concentration lower than normal progesterone was observed. This is seemingly due to receptor down-regulation in the presence of high concentrations of hCG [152-154]. As demonstrated, high concentrations of hCG decrease the number of receptor on cells by degrading the receptor transcript in cells reducing their half-life [152]. Just at the spare receptor mechanism deals with low hCG concentrations at the receptor level, the down-regulation mechanism deals with high hCG concentrations at the receptor level. Assumingly the same as reported to happen at the corpus luteal hCG/LH receptor occurs at the decidua, myometrium, fetal organ, uterine vasculature and human brain receptors. Assumingly, it also happens at the hyperglycosylated hCG or TGF $\beta$ antagonism site. The end result is that the hCG and hyperglycosylated hCG variation paradox may be a simple case of "nature takes care of it."

\section{The $\mathrm{hCG} / \mathrm{LH}$ receptor}

The hCG/LH receptor is located on corpus luteal cells of the ovary for promotion of progesterone, on the decidua for initial communication with the blastocyst on myometrial tissue for growth in line with fetus and for muscle relaxation, on uterine vasculature for angiogenesis, on umbilical cord tissue for growth, on fetal organs for growth and differentiation, on cytotrophoblast cells for differentiation, and on human brain cells, leading to hyperemesis gravidarum. The hCG/LH receptor responds to hCG, LH and hyperglycosylated hCG, but not hCG free subunits or nicked hCG [155]. There is solid evidence showing that the $\alpha$-subunit has a role in receptor binding and $\beta$-subunit has a function in receptor specificity $[156,157]$. The human hCG/LH receptor comprises 675 amino acids [158-160]. The hCG/LH receptor is located on human chromosome $2 \mathrm{p} 21$, with 11 exons and 10 introns [161-163], exons $1-10$ and a portion of exon 11 encode the extracellular domain [164]. hCG/LH receptor sequence and cloning studies indicate that it is part of a large family of guanine nucleotide binding proteins (G-protein), membrane coupled receptors $[165,166]$.

Stimulation by hCG or LH, activates the G-protein, resulting in the stimulation of the membrane bound adenylate cyclase (Figure 2). Activation of adenylate cyclase catalyses the conversion of ATP to cAMP elevating intracellular levels (Figure 2). Following upregulation of cAMP, activation of phosphokinase A then occurs, resulting in phosphorylation and activation of the cAMP responsive element [159].

Activation of protein kinase activates the mitogen protein kinase pathways and a Janus-kinase signaling pathway [167]. All endocrine functions involve DNA transcription or generation of mRNA. Promotion of progesterone production in corpus luteal cells involves the synthesis of cholesterol side-chain cleavage enzyme. Fetal tissue growth involves protein synthesis. A parallel mechanism enhances the synthesis of an hCG/LH receptor binding protein. This activates exo- and endonuclease and leads to the destruction of receptor mRNA. This mechanism limits receptor expression, effectively down-regulating the receptor [168].

Other studies indicate an inositol phospholipid protein kinase-C mechanism is involved in the action of hCG/ LH receptors [159]. Davis and colleagues [169] and Guderman and colleagues [169] show that LH and hCG stimulate a phospholipase $\mathrm{C}$, leading to stimulation of protein kinase $\mathrm{C}$ and activation of $\mathrm{hCG} / \mathrm{LH}$ receptor. 


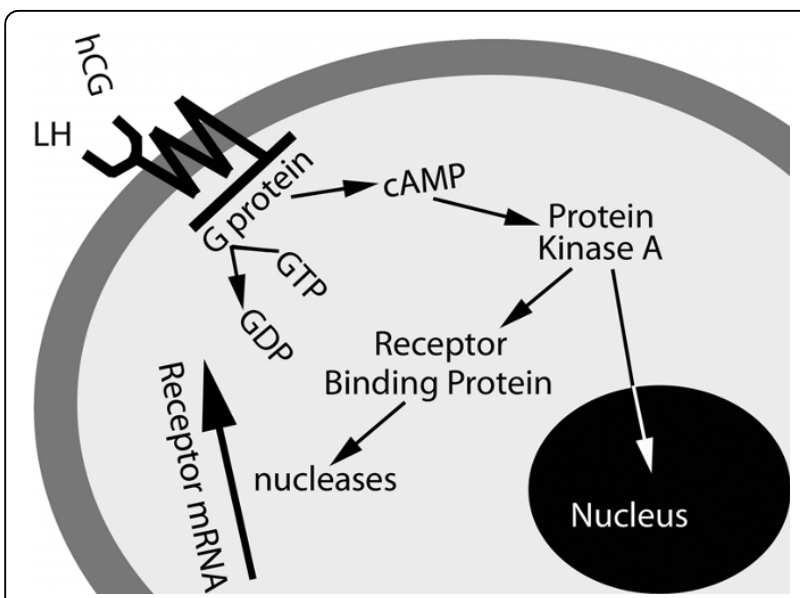

Figure 2 Activation of hCG/LH receptor, G protein and CAMP, protein kinase expression, and production of $\mathrm{hCG} / \mathrm{LH}$ receptor binding protein (LHRBP). Synthesis of LHRBP activates exo- and endonucleases which destroy receptor mRNA, limiting expression and down regulating the receptor.

Moreover, recent data suggest that in the case of hCG signaling at implantation and production of natural killer cells binding with a mannose receptor may be the activation mechanism $[170,171]$. Mutiple pathways are proposed here for $\mathrm{hCG} / \mathrm{LH}$ receptor activation. While they may all be effective in different cells, they all have to be carefully considered as parts of the principal receptor mechanism.

\section{Competing interests}

The author declares that they have no competing interests.

Received: 14 June 2010 Accepted: 24 August 2010

Published: 24 August 2010

\section{References}

1. Aschner B: Ueber die function der hypophyse. Pflug Arch Gest Physiol 1912, 146:1-147.

2. Fellner $\mathrm{OO}$ : Experimentelle untersuchungen uber die wirkung von gewebsextrakten aus der plazenta und den weiblichen sexualorganen auf das genital. Arch Gynakol 1913, 100:641

3. Hirose T: Experimentalle histologische studie zur genese corpus luteum. Mitt Med Fakultd Univ ZU 1919, 23:63-70.

4. Aschheim S, Zondek B: Das Hormon des hypophysenvorderlappens: testobjekt zum Nachweis des hormons. Klin Wochenschr 1927, 6:248-252.

5. Hoshina M, Boime I, Mochizuki M: Cytological localization of hPL, hCG, and mRNA in chorionic tissue using in situ hybridization. Acta Obstet Gynaecol Japonica 1984, 36:397-404

6. Handschuh K, Guibourdenche J, Tsatsaris V, Guesnon M, Laurendeau I, Evain-Brion D, Fournier T: Human chorionic gonadotropin produced by the invasive trophoblast but not the villous trophoblast promotes cell invasion and is down-regulated by peroxisome proliferator-activated receptor-a. Endocrinol 2007, 148:5011-5019.

7. Kovalevskaya G, Genbacev O, Fisher SJ, Cacere E, O'Connor JF: Trophoblast origin of hCG isoforms: cytotrophoblasts are the primary source of choriocarcinoma-like hCG. Mol Cellular Endocrinol 2002, 194:147-155.

8. Sasaki Y, Ladner DG, Cole LA: Hyperglycosylated hCG the source of pregnancy failures. Fertil Steril 2008, 89:1871-1786.
9. Cole LA, Dai D, Butler SA, Leslie KK, Kohorn El: Gestational trophoblastic diseases: 1. Pathophysiology of hyperglycosylated hCG-regulated neoplasia. Gynecol Oncol 2006, 102:144-149.

10. Cole LA: Structures of free $\alpha$-subunit and free $\beta$-subunit. In: Human chorionic gonadotropin (hCG).Edited by: Cole LA. Elsevier, Oxford; 2010:

11. Butler SA, Ikram MS, Mathieu S, lles RK: The increase in bladder carcinoma cell population induced by the free beta subunit of hCG is a result of an anti-apoptosis effect and not cell proliferation. Brit J Cancer 2000, 82:1553-1556.

12. Iles RK, Ectopic hCG $\beta$ expression by epithelial cancer: Malignant behavior metastasis and inhibition of tumor cell apoptosis. Molec Cellul Endocrinol 2007, 260:264-270

13. Cole LA, Ladner DG: Background hCG in Non-Pregnant Individuals: Need for More Sensitive Point-of-Care and Over-the-Counter Pregnancy Tests. Clin Biochem 2009, 42:168-175.

14. Cole LA: Background hCG. In Human chorionic gonadotropin (hCG). Edited by: Cole LA. Elsevier, Oxford; 2010:

15. Schalch DS, Parlow AF, Boon RC, Reichlin S: Measurement of human luteinizing hormone in plasma by radioimmunoassay. J Clin Invest 1968, 47:665-678.

16. Faiman C, Ryan RJ, Zwirek SJ, Rubin ME: Serum FSH and HCG during human pregnancy and puerperium. J Clin Endocrinol Metab 1968, 28:1323-1329.

17. Rao CV, Griffin LP, Carman FR Jr: Prostaglandin F2 alpha binding sites in human corpora lutea. J Clin Endocrinol Metab 1977, 44:1032-1037.

18. Strott CA, Yoshimi T, Ross GT, Lipsett MB: Ovarian physiology: relationship between plasma $\mathrm{LH}$ and steroidogenesis by the follicle and corpus luteum; effect of HCG. J Clin Endocrinol Metab 1969, 29:1157-1167.

19. Cedard L, Varangot J, Yannotti S: The metabolism of estrogens in human placentas artificially maintained in survival by perfusion in vitro. Comptes Rendus Hebdomadaires Seances de l'Academie des Sci 1962, 254:1870-1871.

20. Azuma K, Calderon I, Besanko M, MacLachlan V, Healy DL: Is the luteoplacental shift a myth? Analysis of low progesterone levels in successful art pregnancies. J Clin Endocrinol Metab 1993, 77:195-198.

21. Mayerhofer A, Fritz S, Grunert R, Sanders SL, Duffy DM, Ojeda SR, Stouffer RL: D1-Receptor, DARPP-32, and PP-1 in the primate corpus luteum and luteinized granulosa cells: evidence for phosphorylation of DARPP-32 by dopamine and human chorionic gonadotropin. J Clin Endocrinol Metab 2000, 85:4750-4757.

22. Pierce JG, Parsons TF: Glycoprotein hormones: structure and function. Ann Rev Biochem 1981, 50:65-95.

23. Rao CV: Differential properties of human chorionic gonadotropin and human luteinizing hormone binding to plasma membranes of bovine corpora luteal. Acta Endocrinol 1979, 90:696-710.

24. Berndt S, Blacher S, d'Hauterive PS, Thiry M, Tsampalas M, Cruz A Pequeux C, Lorquet S, Munaut C, Noel A, Foidart JM: Chorionic gonadotropin stimulation of angiogenesis and pericyte recruitment. J Clin Endocrinol Metab 2009, 94:4567-4574.

25. Toth P, Li X, Rao CV, Lincoln SR, Sanfillipino JS, Spinnato JA, Yussman MA: Expression of functional human chorionic gonadotropin/human luteinizing hormone receptor gene in human uterine arteries. J Clin Endocrinol Metab 1994, 79:307-315.

26. Lei ZM, Reshef E, Rao CV: The expression of human chorionic gonadotropin/luteinizing hormone receptors in human endometrial and myometrial blood vessels. J Clin Endocrinol Metab 1992, 75:651-659.

27. Zygmunt M, Herr F, Keller-Schoenwetter S, Kunzi-Rapp K, Munstedt K, Rao CV, Lang U, Preissner KT: Characterization of human chorionic gonadotropin as a novel angiogenic factor. J Clin Endocrinol Metab 2002, 87:290-5296.

28. Herr F, Baal N, Reisinger K, Lorenz A, McKinnon T, Preissner KT, Zygmunt M: hCG in the regulation of placental angiogenesis. Results of an in vitro study. Placenta 2007, 28(Suppl A):S85-93.

29. Zygmunt M, Herr F, Munstedt K, Lang U, Liang OD: Angiogenesis and vasculogenesis in pregnancy. Euro J Obstet Gynecol Reprod Biol 2003, 110(Suppl 1):S10-18

30. Toth P, Lukacs H, Gimes G, Sebestyen A, Pasztor N, Paulin F, Rao CV Clinical importance of vascular hCG/LH receptors-A review. Reprod Biol 2001, 1:5-11.

31. Shi QJ, Lei ZM, Rao CV, Lin J: Novel role of human chorionic gonadotropin in differentiation of human cytotrophoblasts. Endocrinol 1993, 132:387-395 
32. Cronier L, Bastide B, Herve JC, Deleze J, Malassine A: Gap junctional communication during human trophoblast differentiation: influence of human chorionic gonadotropin. Endocrinology 1994, 135:402-408.

33. Akoum A, Metz CN, Morin M: Marked increase in macrophage migration inhibitory factor synthesis and secretion in human endometrial cells in response to human chorionic gonadotropin hormone. J Clin Endocrinol Metab 2005, 90:2904-2910.

34. Matsuura T, Sugimura M, Iwaki T, Ohashi R, Kanayama N, Nishihira J: Antimacrophage inhibitory factor antibody inhibits PMSG-hCG-induced follicular growth and ovulation in mice. J Assist Reprod Genet 2002, 19:591-595.

35. Wan H, Marjan A, Cheung WW, Leenen PJM, Khan NA, Benner R, Kiekens RCM: Chorionic gonadotropin can enhance innate immunity by stimulating macrophage function. J Leukocyte Biol 2007, 82:926-933.

36. Kamada M, Ino H, Naka O, Irahara M, Daitoh T, Mori K, Maeda N, Maegawa M, Hirano K, Aono T: Immunosuppressive 30-kDa protein in urine of pregnant women and patients with trophoblastic diseases. Eur $J$ Obstet Gynecol Reprod Biol 1993, 50:219-225.

37. Noonan FP, Halliday WJ, Morton H, Clunie GJA: Early pregnancy factor is immunosuppressive. Nature 1879, 278:649-651.

38. Majumdar S, Bapna BC, Mapa MK, Gupta AN, Devi PK, Subrahmanyam D: Pregnancy specific proteins: suppression of in vitro blastogenic response to mitogen by these proteins. Int J Fertil 1982, 27:66-69.

39. Reshef E, Lei ZM, Rao CV, Pridham DD, Chegini N, Luborsky JL: The presence of gonadotropin receptors in nonpregnant human uterus, human placenta, fetal membranes, and decidua. J Clin Endocrinol Metab 1990, 70:421-430.

40. Zuo J, Lei ZM, Rao CV: Human myometrial chorionic gonadotropin/ luteinizing hormone receptors in preterm and term deliveries. $J$ Clin Endocrinol Metab 1994, 79:907-911.

41. Eta $E$, Ambrus $G$, Rao V: Direct regulation of human myometrial contractions by human chorionic gonadotropin. J Clin Endocrinol Metab 1994, 79:1582-1586.

42. Doheny HC, Houlihan DD, Ravikumar N, Smith TJ, Morrison JJ: Human chorionic gonadotrophin relaxation of human pregnant myometrium and activation of the BKCa channel. J Clin Endocrinol Metab 2003, 88:4310-4315.

43. Edelstam G, Karlsson C, Westgren M, Löwbeer C, Swahn ML: Human chorionic gonadatropin (hCG) during third trimester pregnancy. Scand J Clin Lab Invest 2007, 67:519-525.

44. Goldsmith PC, McGregor WG, Raymoure WJ, Kuhn RW, Jaffe RB: Cellular localization of chorionic gonadotropin in human fetal kidney and liver. $J$ Clin Endocrinol Metab 1983, 57:54-61.

45. Abdallah MA, Lei ZM, Li X, Greenwold N, Nakajima ST, Jauniaux E, Rao CV: Human Fetal nongonadal tissues contain human chorionic gonadotropin/luteinizing hormone receptors. J Clin Endocrinol Metab 2004, 89:952-956.

46. Rao CV: Paradigm shift on the targets of hCG actions. In Human chorionic gonadotropin (hCG). Edited by: Cole LA. Elsevier, Oxford UK; 2010:, Chapter 11.

47. Rao CV: Nongonadal actions of LH and hCG in reproductive biology and medicine. Sem Reprod Med 2001, 19:1-119.

48. Rao CV: An overview of the past, present and future of nongonadal hCG/LH actions in reproductive biology and medicine. Sem Reprod Endocrinol 2001, 19:7-17.

49. Rao CV, Lei ZM: The past, present and future of nongonadal hCG/LH actions in reproductive biology and medicine. Molec Cell Endocrinol 2007, 269:2-8.

50. McGregor WG, Raymoure WJ, Kuhn RW, Jaffe RB: Fetal tissues can synthesize a placental hormone. Evidence for chorionic gonadotropin $\beta$ subunit synthesis by human fetal kidney. J Clin Invest 1981, 68:306-309.

51. Rao CV, Li X, Toth P, Lei ZM: Expression of epidermal growth factor, transforming growth factor-alpha and their common receptor genes in human umbilical cords. J Clin Endocrinol Metab 1995, 80:1012-1020.

52. Rao CV, Li X, Toth P, Lei ZM, Cook VD: Novel expression of functional human chorionic gonadotropin/luteinizing hormone receptor in human umbilical cords. J Clin Endocrinol Metab 1993, 77:1706-1714.

53. Wasowicz, Derecka K, Stepien A, Pelliniemi L, Doboszynska T, Gawronska B, Ziecik AJ: Evidence for the presence of luteinizing hormone-chorionic gonadotrophin receptors in the pig umbilical cord. J Reprod Fertil 1999, 117:1-9.
54. Ohlsson R, Larsson E, Nilsson O, Wahlstrom T, Sundstrom P: Blastocyst implantation precedes induction of insulin-like growth factor II gene expression in human trophoblasts. Developm 1989, 106:555-559.

55. d'Hauterive SP, Berndt BS, Tsampalas M, Charlet-Renard C, Dubois M, Bourgain C, Hazout A, Foidart JB, Geenen V: Dialogue between Blastocyst hCG and Endometrial hCG/LH Receptor: Which Role in Implantation? Gynecol Obstet Invest 2007, 64:156-160.

56. Joshi NJ, Nandedkar TD: Effects of intrauterine instillation of antiserum to hCG during early pregnancy in mice. Acta Endocrinol 1984, 107:268-274.

57. Srisuparp S, Strakova Z, Fazleabas AT: The Role of Chorionic Gonadotropin (CG) in Blastocyst Implantation. Arch Med Res 2001, 32:627-634, 58. Eblan A, Bao S, Lei ZM, Nakajima ST, Rao CV 2001 The presence of functional luteinizing hormone/chorionic gonadotropin receptor in human sperm J Clin Endocrinol Metab 86:2643-2648.

58. Tsampalasa M, Grideleta V, Berndt S, Foidart JM, Geenena V, d'Hauterive SP: Human chorionic gonadotropin: A hormone with immunological and angiogenic properties. J Repod Immunol 2010.

59. d'Hauterive SP: Implantation: the first maternal-embryo crosstalk. [http:// hdl.handle.net/2268/28418/].

60. Licht $P$, Russu $V$, Wildt $L$ : On the role of human chorionic gonadotropin (hCG) in the embryo-endometrial microenvironment: implications for differentiation and implantation. Semin Reprod Med 2001, 19(1):37-47.

61. Lei ZM, Toth P, Rao CV, Pridham D: Novel coexpression of human chorionic gonadotropin ( $\mathrm{hCG}$ )/human luteinizing hormone receptors and their ligand hCG in human fallopian tubes. J Clin Endocrinol Metab 1993, 77:863-872.

62. Rao CV: Physiological and pathological relevance of human uterine hCG/ LH receptors. J Soc Gynecol Invest 2006, 13:77-78.

63. Gawronska B, Paukku T, Huhtaniemi I, Wasowicz G, Ziecik AJ: Oestrogendependent expression of $\mathrm{hCG} / \mathrm{LH}$ receptors in pig fallopian tube and their role in relaxation of the oviduct. J Reprod Fertil 1999, 115:293-301.

64. Licht $P$, Fluhr $H$, Neuwinger J, Wallwiener D, Wildt L: Is human chorionic gonadotropin directly involved in the regulation of human implantation? Molec Cellul Endocrinol 2007, 269:85-92.

65. Fluhr H, Bischof-Islami D, Krenzer S, Licht P, Bischof P, Zygmunt M: Human chorionic gonadotropin stimulates matrix metalloproteinases- 2 and -9 in cytotrophoblastic cells and decreases tissue inhibitor of metalloproteinases-1, -2 , and -3 in decidualized endometrial stromal cells. Fertil Steril 2008, 90:1390-1395.

66. Reis FM, Cobellis L, Luisi S, Driul L, Florio P, Faletti A, Petraglia F: Paracrine/ autocrine control of female reproduction. Gynecol Endocrinol 2000 $14: 464-475$.

67. Ticconi C, Zicari A, Belmonte A, Realacci M, Rao ChV, Piccione E Pregnancy-promoting actions of HCG in human myometrium and fetal membranes. Placenta 2009, 28:S137-143.

68. Lei ZM, Rao CV, Kornyei J, Licht P, Hiatt ES: Novel expression of human chorionic gonadotropin/luteinizing hormone receptor gene in brain. Endocrinol 1993, 132:262-270

69. Rao CV: Immunocytochemical localization of gonadotropin and gonadal steroid receptors in human pineal glands. J Clin Endocrinol Metab 1997, 82:2756-2757.

70. Wu H, Lustbader JW, Liu Y, Canfield RE, Hendrickson WA: Structure of human chorionic gonadotropin at 2.6 å resolution from MAD analysis of the selenomethionyl protein. Structure 1994, 2:545-58.

71. Hamade AL, Nakabayashi K, Sato A, Kiyoshi K, Takamatsu Y, LaoagFernandez JB, Ohara N, Maruo T: Transfection of antisense chorionic gonadotropin $\beta$ gene into choriocarcinoma cells suppresses the cell proliferation and induces apoptosis. J Clin Endocrinol Metab 2005, 90:4873-4879.

72. Cole LA: Biological functions of hyperglycosylated hCG. In Human chorionic gonadotropin (hCG). Edited by: Cole LA. Elsevier, Oxford UK; 2010:, Chapter 13.

73. Schuster N, Krieglstein K: Mechanisms of TGF- $\beta$-mediated apoptosis. Cell Tissue Res 2002, 307:1-14

74. Kamijo T, Rajabi MR, Mizunuma H, Ibuki Y: Biochemical evidence for autocrine/paracrine regulation of apoptosis in cultured uterine epithelial cells during mouse embryo implantation in vitro. Molec Human Reprod 1998, 4:990-8.

75. Pampferf S: Apoptosis in rodent peri-implantation embryos: differential susceptibility of inner cell mass and trophectoderm cell lineages-A review. Placenta 2000, 21:S3-S10. 
76. Shooner C, Caron PC, Fréchette-Frigon G, Leblanc V, Déry MC, Asselin E: TGF-beta expression during rat pregnancy and activity on decidual cell survival. Reprod Biol Endocrinol 2005, 3:20.

77. Liu Y-X, Gao F, Wei P, Chen X-L, Gao H-J, Zou R-Z, Siao L-J, Xu F-H, Feng Q, Liu K, Hu Z-Y: Involvement of molecules related to angiogenesis, proteolysis and apoptosis in implantation in rhesus monkey and mouse. Contraception 2005, 71:249-62.

78. Knittel T, Mehde M, Kobold D, Saile B, Dinter C, Ramadori G: Expression patterns of matrix metalloproteinases and their inhibitors in parenchymal and non-parenchymal cells of rat liver regulation by TNFalpha and TGF-beta1. J Hepatol 1999, 30:48-60.

79. Murphy G, Reynolds JJ, Whitham SE, Docherty AJ, Angel P, Heath JK: Transforming growth factor beta modulates the expression of collagenase and metalioproteinase inhibitor. Euro Molec Biol Org J 1987, 6:1899-1904.

80. Qureshi HY, Sylvester J, El Mabrouk M, Zafarullah M: TGF-beta-induced expression of tissue inhibitor of metalloproteinases-3 gene in chondrocytes is mediated by extracellular signal-regulated kinase pathway and Sp1 transcription factor. J Cell Physiol 2005, 203:345-52.

81. Stetler-Stevenson WG, Brown PD, Onisto M, Levy AT, Liotta LA: Tissue inhibitor of metalloproteinases-2 (TIMP-2) mRNA expression in tumor cell lines and human tumor tissues. J Biol Chem 1990, 265:13933-13938.

82. Pringle $K$, Roberts C: New light on early post-implantation pregnancy in the mouse: roles for insulin-like growth factor-II (IGF-II)? Placenta 2007, 28:286-97.

83. Hwang JH, Koh SH, Han DI, Chung SR, Park Ml, Hwang YY, Jang SJ: Expression of transforming growth factor-1, 2 in the decidua of the early pregnancy: Comparison of decidua basalis and decidua parietalis. Korean J Obstet Gynecol 2001, 44:1145-9.

84. Kingsley-Kallesen M, Johnson L, Scholtz B, Kelly D, Rizzino A: Transcriptional regulation of the TGF-beta 2 gene in choriocarcinoma cells and breast carcinoma cells: Differential utilization of Cis-regulatory elements. In Vitro Cell Dev Bio Anim 1997, 33:294-301.

85. Staun-Ram E, Shaleu E: Human trophoblast function during the implantation process. Reprod Biol Endocrinol 2005, 3:56-68.

86. Fisher SJ, Tian-yi C, Li Z, Hartman L, Grahl K, Zhang G-Y, Tarpey J, Damsky $\mathrm{CH}$ : Adhesive and degradative properties of human placental cytotrophoblast cell in vitro. J Cell Biol 1989, 109:891-902.

87. Cole LA, Khanlian SA, Riley JM, Butler SA: Hyperglycosylated hCG (hCG-H) in Gestational Implantation, and in Choriocarcinoma and Testicular Germ Cell Malignancy Tumorigenesis. J Reprod Med 2006, 51:919-929.

88. Lei ZM, Taylor DD, Gercel-Taylor C, Rao CV: Human chorionic gonadotropin promotes tumorigenesis of choriocarcinoma JAR cells. Troph Res 1999, 13:147-159.

89. Norwitz ER, Schust DJ, Fisher SJ: Implantation and the survival of early pregnancy. N Engl J Med 2001, 345:1400-8.

90. Jauniaux E, Poston L, Burton GJ: Placenta-related disease of pregnancy: involvement of oxidative stress and implications in human evolution. Hum Reprod Update 2006, 12:747-56.

91. Kovalevskaya G, Birken S, Kakuma T, Ozaki N, Sauer M, Lindheim S, Cohen M, Kelly A, Schlatterer J, O'Connor JF: Differential expression of human chorionic gonadotropin (hCG) glycosylation isoforms in failing and continuing pregnancies: preliminary characterization of the hyperglycosylated hCG epitope. J Endocrinol 2002, 172:497-506.

92. Burton GJ: Placental oxidative stress: From miscarriage to preeclampsia. $J$ Soc Gyn Invest 2004, 11:342-52.

93. Salas SP: What causes pre-eclampsia? Clin Obstet Gyncol 1999, 13:141-57.

94. Bahado-Singh RO, Oz U, Isozaki T, Seli E, Kovanci E, Hsu CD, Cole LA: Midtrimester urine $\beta$-subunit core fragment levels and the subsequent development of preeclampsia. Am J Obstet Gynecol 1998, 179:738-741.

95. Cole LA: Structures of free $\alpha$-subunit and free $\beta$-subunit. In Human chorionic gonadotropin (hCG). Edited by: Cole LA. Elsevier, Oxford UK; 2010:, Chapter 7.

96. Valmu L, Alfthan H, Hotakainen K, Birken S, Stenman UH: Site-specific glycan analysis of human chorionic gonadotropin [beta]-subunit from malignancies and pregnancy by liquid chromatography - electrospray mass spectrometry. Glycobiology 2006, 16:1207-1218.

97. Acevedo HF, Tong JY, Hartsock RJ: Human chorionic gonadotropin-beta subunit gene statement in cultured human fetal and cancer cells of different types and origins. Cancer 1995, 76:1467-1475.
98. Acevedo HF, Hartstock RJ: Metastatic phenotype correlates with high expression of membrane-associated complete $\beta$-human chorionic gonadotropin in vivo. Cancer 1996, 78:2388-2399.

99. Li D, Wen X, Ghali L, Al-Shalabi FM, Docherty SM, Purkis P, Iles RK: hCG expression by cervical squamous carcinoma - in vivo histological association with tumor invasion and apoptosis. Histopathology 2008, 53:147-155.

100. Iles RK: Ectopic hCG $\beta$ expression by epithelial cancer: Malignant behavior metastasis and inhibition of tumor cell apoptosis. Molec Cellul Endocrinol 2007, 260:264-270

101. Iles RK: Human chorionic gonadotrophin and its fragments as markers of prognosis in bladder cancer. Tum Mark Upd 1995, 7:161-166.

102. Cole LA: $\beta$-core fragment ( $\beta$-core UGP or UGF). Tum Mark Upd 1994, 6:69-75.

103. Mountzouris G, Yannapoulis D, Barbatis C, Zaharof A, Theodorou C: Is $\beta$ human chorionic gonadotrophin production by transitional cell carcinoma of the bladder a marker of aggressive disease and resistance to radiotherapy? $\mathrm{Br} J$ Urol 1993, 72:907-909.

104. Butler SA, lles RK: Ectopic human chorionic gonadotrophin $\beta$ secretion by epithelial tumors and human chorionic gonadotrophin $\beta$-induced apoptosis in Karposi's sarcoma Is there a connection? Clin Cancer Res 2003, 9:4666-4673.

105. Bellet D, Lazar V, Bleche I, Paradis V, Giovangrandi Y, Paterliru P: Malignant transformation of nontrophoblastic cells in association with the expression of chorionic gonadotropin $\beta$ genes normally transcribed in trophoblastic cells. Cancer Res 1997, 57:516-523.

106. Cosgrove DE, Campain JA, Cox GS: Chorionic gonadotropin synthesis by human tumor cell lines: Examination of subunit accumulation steadystate levels of mRNA and gene structure. Biochem Biophys Acta 1989, 1007:44-54.

107. Butler SA, Ikram MS, Mathieu S, lles RK: The increase in bladder carcinoma cell population induced by the free beta subunit of hCG is a result of an anti-apoptosis effect and not cell proliferation. Brit J Cancer 2000, 82:1553-1556.

108. Cole LA, Perini F, Birken S, Ruddon RW: An oligosaccharide of the O-linked type distinguishes the free from the combined form of hCG alphasubunit. Biochem Biophys Res Comm 1984, 122:1260-1267.

109. Gillott DJ, lles RK, Chard T: The effects of human chorionic gonadotropin on AIDS related Karposis sarcoma. N Engl J Med 1996, 335:1261-1269.

110. Delves PJ, lles RK, Roitt IM, Lund T: Designing a new generation of antihCG vaccines for cancer therapy. Molec Cellular Endocrinol 2007, 260:276-281

111. Delves PJ, Roitt IM: Vaccines for the control of reproduction-status in mammals and aspects of comparative interest. Developm Biologic 2005, 121:265-273.

112. Guan QD, Wang Y, Chu YW, Wang LX, Ni J, Guo Q, Xiong SD: The distinct effects of three tandem repeats of $\mathrm{C} 3 \mathrm{~d}$ in the immune responses against tumor-associated antigen hCGbeta by DNA immunization. Cancer Immunol Immunother 2007, 56:875-884.

113. Iversen PL, Mourich DV, Moulton HM: Monoclonal antibodies to two epitopes of $\beta$-human chorionic gonadotropin for the treatment of cancer. Cur Opin Molec Therap 2003, 5:156-160.

114. Moulton HM, Yoshihara PH, Mason DH, Iversen PL, Triozzi PL: Active specific immunotherapy with $\beta$-human chorionic gonadotropin peptide vaccine in patients with metastatic colorectal cancer: Antibody response is associated with improved survival. Clin Cancer Res 2002, 8:2044-2051.

115. Carter WB, Sekharem M, Coppola D: Human chorionic gonadotropin induces apoptosis in breast cancer. Breast Cancer Res Treatm 2006, 100 S243-S244.

116. Khoo NK, Bechberger JF, Shepherd T, Bond SL, McCrae KR, Hamilton GS, Lala PK: SV40 Tag transformation of the normal invasive trophoblast results in a premalignant phenotype I Mechanisms responsible for hyperinvasiveness and resistance to anti-invasive action of TGF $\beta$. Int/ J Cancer 1998, 77:429-39.

117. Khoo NK, Bechberger JF, Shepherd T, Bond SL, McCrae KR, Hamilton GS, Lala PK: SV40 Tag transformation of the normal invasive trophoblast results in a premalignant phenotype I Mechanisms responsible for hyperinvasiveness and resistance to anti-invasive action of TGF $\beta$. Int/ J Cancer 1998, 77:429-39.

118. Karmakar S, Das C: Regulation of Trophoblast Invasion by IL-1 $\beta$ and TGFB1. Am J Reprod Immunol 2002, 48:210-219. 
119. Graham CH, Lala PK: Mechanism of control of trophoblast invasion in situ. J Cell Physiol 1991, 148:228-34.

120. Smith A: Characterization of a TGF $\beta$-responsive Human Trophoblastderived Cell Line. Placenta 2001, 22:425-431.

121. Staun-Ram E, Shaleu E: Human trophoblast function during implantation process. Reprod Biol Endocrinol 2005, 3:56.

122. Butler SA, Staite EM, lles RK: Reduction of bladder cancer cell growth in response to hCG beta CTP37 vaccinated mouse serum. Oncol Res 2003, 14:93-100.

123. Acevedo HF, Slifkin M, Pouchet GR, Pardo M: Immunochemical localization of a choriogonadotropin-like protein in bacteria isolated from cancer patients. Cancer 1978, 41:1217-29.

124. Backus BT, Affronti LF: Tumor-asociated bacteria capable of producing human choriogonadotropin-like substance. Infect Immun 1981, 32:1211-15.

125. Maruo T, Segal SJ, Koide SS: Studies on the apparent human chorionic gonadotropin-like factor in crab Ovalipes ocellatus. Endocrinol 1979, 104:932-9.

126. Cole LA, Muller Y: $\mathrm{hCG}$ in the management of quiescent and chemorefractory gestational trophoblastic diseases. Gyn Oncol 2010, 116:3-9.

127. Cole LA, Laidler LL: Inherited hCG. J Reprod Med 2010, 55:99-102.

128. Matsuura S, Ohashi M, Chen HC, Shownkeen RC, Hartree AS, Reichert LE Jr, Stevens VC, Powell JE: Physicochemical and immunological characterization of an hCG-like substance from human pituitary glands. Nature 1980, 286:740-1.

129. Cole LA, Khanlian SA, Muller CY: Detection of hCG peri- or postmenopause an unnecessary source of alarm. Am J Obstet Gynecol 2008, 198:275-9.

130. Cole LA, Sasaki Y, Muller CY: Normal production of hcg in menopause: A medical management dilemma. N Eng J Med 2007, 356:1184-6.

131. Gronowski AM, Fantz CR, Parvin CA, Sokoll LJ, Wiley CL, Wener MH, Grenache D: Use of serum FSH to identify perimenopausal women with pituitary hCG. Clin Chem 2008, 54:652-6.

132. Cole LA, Khanlian SA: Inappropriate management of women with persistent low hCG results. J Reprod Med 2004, 49:423-32.

133. Birken S, Maydelman Y, Gawinowicz MA, Pound A, Liu Y, Hartree AS Isolation and characterization of human pituitary chorionic gonadotropin. Endocrinol 1996, 137:1402-11.

134. Hoermann R, Spoettl G, Moncayo R, Mann K: Evidence for the presence of human chorionic gonadotropin (hCG) and free beta-subunit of hCG in the human pituitary. J Clin Endocrinol Metab 1990, 71:179-86.

135. Odell WD, Griffin J: Pulsatile secretion of human chorionic gonadotropin in normal adults. N Engl J Med 1987, 317:1688-91.

136. Odell WD, Griffin J: Pulsatile secretion of chorionic gonadotropin during the normal menstrual cycle. J Clin Endocrinol Metab 1989, 69:528-32.

137. Policastro PF, Daniels-McQueen S, Carle G, Boime I: A map of the hCG beta-LH beta gene cluster. J Biol Chem 1986, 13:5907-5916.

138. Gougeon A: Dynamics of follicular growth in the human: A model from preliminary results. Human Reprod 1986, 1:81-7.

139. Bogovich K, Richards JS, Reichert LE Jr: Obligatory role of luteinizing hormone (LH) in the initiation of preovulatory follicular growth in the pregnant rat: Specific effects of human chorionic gonadotropin and follicle-stimulating of hormone on $\mathrm{LH}$ receptors and steroidogenesis in theca, granulosa, and luteal cells. Endocrinol 1981, 109:860-7.

140. Motola S, Popliker M, Tsaffiri A: Are steroids obligatory mediators of hCG/ LH triggered resumption of meiosis in mammals? Biol Reprod 2007, 77:167-8.

141. Hegele-Hartung C, Grütznera M, Lessla M, Grøndahl C, Ottesen JL, Brännström M: Activation of meiotic maturation in rat oocytes after treatment with follicular fluid meiosis-activating sterol in vitro and ex vivo. Biol Reprod 2001, 64:418-24.

142. Robkera RL, Russella DL, Yoshiokab S, Sharmaa SC, Lydona JP, O'Malleya BW, Espeyb LL, Richards JS: Ovulation: A multi-gene, multi-step process. Steroids 2000, 65:559-70.

143. Butler TA, Zhu C, Mueller RA, Fuller GC, Lemaire WJ, Woessner JF Jr: Inhibition of ovulation in the perfused rat ovary by the synthetic collagenase inhibitor SC 44463. Biol Reprod 1991, 44:1183-8.

144. Acosta JT, Miyamoto A: Vascular control of ovarian function: Ovulation, corpus luteum formation and regression. Anim Reprod Sci 2004, 82-83, $127-40$.
145. Nalbandov AV, Bahr JM: Ovulation, corpus luteum formation, and steroidogenesis. Basic Life Sci 1974, 4:399-407.

146. Hartree AS, Shownkeen RC, Stevens VC, Matsuura S, Ohashi M, Chen H-C: Studies of human chorionic gonadotropin-like substance of human pituitary glands and its significance. J Clin Endocrinol Metab 1983, 96:115-26.

147. Cole LA: Individual deviations in hCG concentrations during pregnancy. Am J Obstet Gynecol 2010.

148. Cole LA, Ladner DG, Byrn FW: The Normal Variabilities of the Menstrual Cycle and the Menstrual Cycle Leading to Pregnancy. Fertil Steril 2009, 91:522-527.

149. Madsen BW: Spare receptors. Clin Exper Pharm Phys 1979, 6:713-714

150. Siebers JW, Wuttke W, Engel W: hCG-binding of the rat ovary during pregnancy. Acta Endocrinol 1977, 86:173-179.

151. Marunaka M, Niisato N, Miyazaki H: New Concept of Spare Receptors and Effectors. J Membr Biol 2005, 203:31-35.

152. Han SW, Lei ZM, Rao CV: Homolgous down-regulation of luteinizing hormone/chorionic gonadotropin receptors by increasing the degradation of receptor transcripts in human uterine endometrial stromal cells. Biol Reprod 1997, 57:158-164.

153. Rao CV, Sanfillippo JS: New understanding of the biochemistry of implantation. Potential direct roles of luteinizing hormone and human chorionic gonadotropin. Endocrinologist 1997, 7:107-111.

154. Jauniaux E, Bao S, Eblen A, Li X, Liu ZM, Meuris S, Rao ChV: hCG concentration and receptor gene expression in placenta tissue from trisomy 18 and 21. Molec Human Reprod 2000, 6:5-10.

155. Cole LA: New Discoveries on the Biology and detection of Human Chorionic Gonadotropin. Reprod Biol Endocrinol 2009, 7:1-37.

156. Rao CV: Differential properties of human chorionic gonadotrophin and human luteinizing hormone binding to plasma membranes of bovine corpora lutea. Acta Endocrinol 1979, 90:696-710.

157. Dufau ML, Kusuda S: Purification and characterization of ovarian hCG/LH and prolactin receptors. J Recept Res 1987, 7:167-193.

158. Jia XC, Oikawa M, Bo M, Tanaka T, Ny T, Boime I, Hsueh AJ: Expression of human luteinizing hormone $(\mathrm{LH})$ receptor: Interaction with $\mathrm{LH}$ and chrionic gonadotropin from human, but not equine, rat, and ovine species. Mol Endocrinol 1991, 5:759-768.

159. Segaloff DL, Ascoli M: The lutropin/choriogonadotropin receptor - 4 years later. Endocr Rev 1993, 14:324-347.

160. McFarland RC, Sprengel R, Phillips HS, Kohler M, Resemblit N, Nikolics R, Segaloff DL, Seeburg PH: Lutopin-choriogonadotropin receptor: An unusual member of the G protein-coupled receptor family. Science 1989, 245:494-499.

161. Ascoli M, Fanelli F, Segaloff DL: The lutropin/choriogonadotropin receptor, a 2002 perspective. Endocr Rev 2002, 23:141-174.

162. Fanelli F, Puett D: Structural aspects of luteinizing hormone receptor. Endocrine 2002, 18:285-293.

163. Fanelli F, Themman APN, Puett D: Lutropin receptor function: Insights from natural, engineered, and computer-simulated mutations. Int/ Union Biochem Molec Bio Life 2001, 51:149-155.

164. Puett D, Li Y, Agelova K, DeMars G, Meehan TP, Ganelli F, Narayan P: Structure-function relationships of the luteinizing hormone receptor. Ann New York Acad Sci 2005, 1061:41-54.

165. McFarland KC, Sprengel R, Phillips HS, Kohler M, Rosemblit N, Nikolies K, Segaloff DL, Seeburg PH: Lutropin-choriogonadotrophin receptor: An unusual member of the G-protein coupled receptor family. Science 1989, 245:494-499.

166. Loosfelt H, Salesse R, Jallal B, Garnier J, Milgrom E: Cloning and sequencing of porcine LH-hCG receptor CDNA: Variants lacking transmembrance domain. Science 1989, 245:525-528

167. Angelova K, Fanelli F, Puett D: A model for constitutive lutropin recepto activation based on molecular simulation and engineered mutations in transmembrane helices 6 and 7. J Biol Chem 2002, 277:32202-32213.

168. Angelova K, Narayan P, Simon JP, Puett D: Functional role of transmembrane helix 7 in the activation of the heptahelical lutropin receptor. Mol Endocrinol 2000, 14:459-471.

169. Davis JS, Westa LA, Weaklanda LL, Faresea RV: Human chorionic gonadotropin activates the inositol 1,4,5-trisphosphate-Ca2 ${ }^{+}$intracellular signalling system in bovine luteal cells. FEBS Letters 1986, 208:287-291.

170. Guderman T, Birnbaumer M, Birnbaumer L: Evidence for dual coupling of the muring luteinizing hormone receptor to adenylyl cyclase and 
phosphoinositide breakdown and Ca2+ mobilization. J Biol Chem 1992, 267:4479-4488.

171. Kane N, Kelly E, Philippa Saunders TK, Critchley HOD: Proliferation of uterine natural killer cells is induced by hCG and mediated via the mannose receptor. Endocrinol 2009, 150:2882-2888.

doi:10.1186/1477-7827-8-102

Cite this article as: Cole: Biological functions of hCG and hCG-related molecules. Reproductive Biology and Endocrinology 2010 8:102.

Submit your next manuscript to BioMed Central and take full advantage of:

- Convenient online submission

- Thorough peer review

- No space constraints or color figure charges

- Immediate publication on acceptance

- Inclusion in PubMed, CAS, Scopus and Google Scholar

- Research which is freely available for redistribution

Submit your manuscript at www.biomedcentral.com/submit 